\title{
CHINESE INFORMATION WARFARE: \\ A PHANTOM MENACE OR EMERGING \\ THREAT?
}

Toshi Yoshihara

November 2001 